\title{
The Problematics of Race and the Eternal Quest for Freedom: A Postcolonial Reading of Toni Morrison's Novels Within the Context of the Black Lives Matter Protests
}

\author{
Abdelkader Ben Rhit
}

Department of English, University of Gabes, Tunisia

Received: 25 Sep 2021; Received in revised form: 27 Oct 2021; Accepted: 05 Nov 2021; Available online: 12 Nov 2021

(C2021 The Author(s). Published by Infogain Publication. This is an open access article under the CC BY license (https://creativecommons.org/licenses/by/4.0/).

\begin{abstract}
Reading Toni Morrison's selected novels from a postcolonial perspective and within the context of the Black Lives Matter protests (BLM), this paper examines the quest for freedom that is still a dream for the African Americans in the purportedly "post-racial" America. The idea of freedom, which is central in Morrison's novels as well as in the BLM's narrative, has been powerfully affected by slavery, racism, sexism, and classism in the American society. Morrison's narratives and the BLM movement have been remarkable for their divergent routes of the quest for freedom. Like Morrison, who condemned all racially motivated violence against black people and who has attempted, through her novels, to shake white people's collective memories out of dis-remembrance of coloured lives, the Black Lives Matter movement has denounced violence and racism and has demanded accountability from abusers. With reference to Morrison's selected novels, this paper examines how her female protagonists' quest for freedom and for a sense of self emerges from agonising experiences of marginalisation. It investigates how her novels offer a timely exploration of the traumatised Black female body that interrogates, whether Americans have entered a post-racial era. The paper argues that Morrison's novels and the Black Lives Matter protests confirm that the legacy of slavery still dictates the way Black people are seen and treated in twenty-first-century America. Ultimately, what this paper intends is to speak the unspeakable: freedom is still a dream for African American, race still matters despite the silencing effects of "post-racial" discourse.
\end{abstract}

Keywords-Black Lives Matter, Freedom, Postcolonialism, Post-racialism, Toni Morrison.

\section{INTRODUCTION}

Morrison's novels counter and challenge dominant ideologies and representations. From a postcolonial perspective, her writings fit into Helen Tiffin's (1988) definition of the postcolonial literatures and their decolonizing endeavours: "dis/mantling, de/mystification and unmasking of European authority" as well as defining "a denied or outlawed self" (p. 171). In her novels, Morrison critiques the American system of patriarchal racism, sexism, and classism, which is currently in place, exposing issues of race and how this society has denied African Americans' freedom and racial identity. Her fiction shaped a new literary aesthetics that opposes racial ideologies. Morrison portrays black individuals, especially women, marginalized and disenfranchised by the white male-dominated society in which they live. Like Morrison's novels, the Black Lives Matter is a movement of protest against racism and all racially motivated forms of violence. It interrogates the lack of freedom for African Americans, the permanence of racism against them and the eternally deferred social justice. Black people are still 
seeking freedom and racial justice in the purportedly "post-racial” America.

Morrison's novels have become spaces to imagine a US, which supports racial equality and black dignity. Similarly, the Black Lives Matter movement (BLM) has continued to assert itself as a positive and peaceful movement that is not only seeking to promote change but also to find meaning in the mid of suffering and oppression. The protests in the streets are more than repudiations of violence-they are quests for freedom and social justice. Within this context, this paper critically reads Morrison's selected novels from a postcolonial perspective. It examines how Morrison's female protagonists' quest for freedom and for a sense of self emerges from agonising experiences of marginalisation and denial. It explores parallels between the BLM movement and Morrison's narratives and demonstrates the extent to which they can contribute to a social change regarding the inherent issues of racism and injustice in America. Although there is a considerable psychoanalytic criticism of Morrison's work to show the atrocities blacks went through, I have noticed a neglect of the individual struggle Morrison's female protagonists heroically undertake to find their own path to self-construction and freedom. Critics have neglected the theme of freedom which is at the heart of Morrison's novels. This research article is a modest attempt to examine the quest for freedom and to demonstrate that Morrison's record of pain and traumatic experiences is nothing but a positive stage to recovery, a way leading to freedom and self-knowledge.

The first section of this article delineates the commonalities between postcolonialism and African American experience and it analyses Morrison's selected novels from a postcolonial perspective. Some of the key theoretical concepts used in (post)colonial discourse will be explained in this section. The second section examines the traumatic experiences Morrison's female protagonists have gone through to attain their freedom and selfknowledge. The third section shows the parallels and the shared goals between Morrison's fictional writings and the Black Lives Matter narrative and it argues that both narratives disarticulate the post-racial discourse in America.

\section{AFRICAN AMERICAN EXPERIENCE AND POSTCOLONIALISM}

One of the shared goals of Postcolonial and African American studies is to destabilize racial hierarchies. The power relationships between the colonizer and the colonized are similar to relationships between masters and slaves. Their joint critique of neocolonialism and of the current reality of racism towards black people in the American society and in other postcolonies is another common ground between these two fields. Bell Hooks (1994) believes that "black experience has been and continues to be one of internal colonialism" (p.148). Hence the need for decolonizing the mindset of contemporary America.

Imperialism is generally defined as the "control of one nation over the political, cultural and economic life of another" but as Alyson R. Buckman (1995) argues "it may be extended to include internal, as well as external, colonialism" (89). Imperialism is defined as an "economic, political, institutional and cultural phenomenon that has been practiced by power elites in relation to the masses of the United States, especially in relation to Native Americans, blacks, women and immigrant groups such as Asians". Buckman argues that:

the colonial relationship is one of domination and subordination among groups and is constructed primarily on notions of difference; it is established and maintained in order to serve the interest of the dominant group, fortifying its position and eroding choice for non-elites through force, authority, influence and dominance (p.89).

Postcolonial discourse is concerned, among other things, with the experience of discrimination, dehumanization, othering and resistance under oppressive systems of colonial domination. Moreover, postcolonialism is concerned with the politics of resistance to unequal and unjust forms of social, economic, and political authority and it analyses the structure of domination and subordination. In America, the dominant White community has resisted attempts of the "periphery", represented by the black people, to dismantle its oppressive institutions. The institutions of literature and education and the social structures are informed by the cultural formations and values of the dominant white community, which represents the "imperial center". The marginalized African Americans struggle to regain their lost voices and identities in the postcolonial scenario. The literary responses of African Americans have attempted to resist this dominant discourse by rewriting their versions of history and interrogating traditional assumptions of the authoritarian imperial center which segregates and marginalizes the black people in America.

The discourse about African American experience and postcolonialism share a concern for marginalized voices and a rejection of Eurocentrism. The African American experience of slavery and oppression makes it fall under the label postcolonial. Elisabeth Mairhofer and Miriam Meister (2007) state that: 
The term 'postcolonial' does not only refer to the experience of colonialism and the dominance of one nation over the other. The experiences of African Americans and their position in U.S. society can be seen as analogous to the traditional colonial situation: they also suffered from suppression, from the negation of their cultures and identities, and from racism, the only difference being that the colonizer and the colonized, if we want to stick to these terms, lived under the same national and political system (2007, p. 143).

The Manichaean binarism such as white vs. black, self vs. other, master vs. slave, colonizer vs. colonized, oppressor vs. oppressed, the center vs. the marginalized are relevant in the discussion of the African American experience. Due to these concerns discussed above, African American literature is already included within postcolonial literature. Theo D'Haen (1993) widens the scope of postcolonial literature to include all literature which stages a "confrontation between margin and center" (p.12). Both postcolonial literature and African American literature depict a confrontation between self and other and center and margin. This explains why African American texts, such as those of Morrison, can be read as postcolonial. They are written by members of a marginalized ethnic group in America.

African American theorists have used colonial independence struggles in Africa in order to compare the colonized peoples' experience with the experience of African American in 1960s/1970s America. However, because of the differences between the experience of African Americans and that of their colonized counterparts, colonialism in America was labeled "internal colonialism" (Robinson, 2001, p. 81). Due to these commonalities, contemporary African American theorists, black scholars, and civil rights activists continue to use the language of colonization in order to describe the African American experience in America. Bell Hooks (1992) wrote about the "...oppression, exploitation, and overall domination of all black people" (p. 2), and in doing so, obviously made an analogy between the experience of modern-day African Americans and their (post)colonial counterparts. The end of slavery in America did not lead African Americans out of their traumatic past but has plunged them into a new cycle of pathos, subjugation, discrimination, segregation, and inequities. For this reason, one can easily draw a close resemblance between the experiences of African Americans and those of their colonized counterparts elsewhere well into the twentieth century - and in some ways, even in the present day.

From a postcolonial perspective, Morrison's novels have given voice to the voiceless and marginalized African
Americans and have interrogated the oppressive forces which have kept them in the periphery. Morrison's novels bear witness to the traumatic experiences the black people have been through throughout the American history. They describe the African Americans' struggle for survival, their protest against white racism and injustice, and their quest for freedom and identity. Her stories of both individual and collective pain and triumph resonate with the African American experience and human experience in general. She dares to speak out the unspeakable and she rips the veil on the hidden realities of sore ordeals.

Morrison's novels can be qualified as literature of commitment because of their ideological or political stance. She wrote about the predicament of the entire black race_-both men and women "celebrating the strengths of black women against the heavy odds of racism and sexism by developing the necessary political, social and aesthetic consciousness" (Dastageer, 2016, p.21). She strongly supported the cause of the black men and women. Her writings, fictional and non-fictional, demonstrate that she writes for the liberation of her fellow blacks in America.

For Morrison, writing fiction is her weapon to bear witness to the black people's traumatic experiences and to give them voice. She gives full support to the Black women who are the most affected by racism, sexism, and classism. Her novels include traces of the Black Feminism movement though the movement and theory came much later. The significance of empowerment, the legacy of struggle, the quest for freedom, which are the core themes of Black Feminism, are present in her writings. Her novels are mainly about Black women, their traumas, their struggle for survival and freedom from the shackles of racial degeneracy and cultural inferiority. Black women in America have been victimized because of their race, gender, and class (Chapagain, 2020, p.116). Their traumatic psychological condition is caused by racism, sexism, and classism.

Morrison's novels function as political and social commentary. For her, "the function of the novel is... to illuminate and engage with social and cultural conflicts and do justice to their complexities" (Lister, 2009, p.13). She was "conscious of the nature of the African's dilemma, the crisis of the African personality, its cause and effects", and she had "increasing commitment to help solve it in terms of fictional art, thereby combining her political consciousness with aesthetic sensibility" (Dastageer, 2016, p. 21). As a black feminist, Morrison fought against racism, sexism, and gender stereotypes through her fictional and non-fictional works. Black feminism "is not simply a struggle to end male chauvinism or a movement to ensure that women will have equal rights with men; it is a commitment to eradicating the ideology 
of domination that permeates Western culture on various levels- sex, race, and class..." (Hooks, 1981, p. 194). Black feminism has focused on other issues, such as race, which was not addressed by classic feminism.

Wang Anyi explained that "Morrison's feminism is most appealing to [her] for she accounts not only gender but also race and class" (as cited in Wu, 2010, p. 406). All female characters Pecola, Sula, Jadine, Pilate, and Sethe are victims of race, class, and gender in different ways. Though Morrison wrote about the effects of slavery on the psyche of the Black women, it is portrayed from various perspectives, from racism, sexism, classism, and the multifaceted sufferings a black woman has to undergo during the era of slavery and also in the post slavery era. The next paragraphs examine Morrison's representation of black females' suffering and journey to attain freedom and discover their identities.

The Black Lives Matter (BLM), an international social movement, which was formed in the United States in 2013, is dedicated to fighting racism and antiBlack violence, especially in the form of police brutality. It condemns the unjust murdering of Black people by police and it demands that society value the lives and humanity of Black people as much as it values the lives and humanity of white people (Britannica). "Were [Morrison] still alive, she undoubtedly would have thrown her unequivocal support behind the BLM movement and galvanized everyone," argues Konomi Ara who goes on to say, "but Morrison would have supported the cause only through her writing" (cited in The Asahi Shimbun, 2020). Morrison has devoted her life and writings to defend the human rights of the marginalized and voiceless African Americans.

The now "free" Afro-Americans are still subject to various forms of oppression. Their quest for freedom is still an ongoing phenomenon in America. African Americans "bear daily the burdensome trace of violence as 'a tax to pay' for their existence. Evidence is exceedingly spattered on television screens, leaving us shackled, muted by inexpressible shock and awe" (Ben Beya, 2010 p. 86). Reading Morrison's fictional writings within the context of the Black Lives Matter protests, this chapter analyses Morrison's female protagonists' traumatic experiences, their endurance, and their quest for freedom. It focuses on the fact that these very unbearable conditions reveal the characters' basic nature as heroines coming to terms with the real meaning of their existence. It shows how every character bears the weight of responsibility for his own life and at last finds the way lifting him up from his own and other's guilt to progresses and glory.

The idea of freedom, which is central in Morrison novels, has been powerfully affected by slavery, racism, injustice, and inequality in the American society. Almost all Morrison's novels have been remarkable for their different routes of quest for freedom. Like the Black Lives Matter protests, Morrison's novels have attempted to shake white people's collective memories out of disremembrance of coloured lives and to demand accountability from abusers. The Bluest Eye, Sula, Song of Solomon, Tar Baby, and Beloved are novels of protest against, white racism, sexism, patriarchy, and slavery. They are blues songs for the "disremembered and unaccounted for" (Beloved, 1987, p. 274) -because they delineate the black female protagonists' journey of struggle for survival, their protest against the various forms of oppression they have been subject to by both the whites and the blacks, and finally their freedom and assertion of their black selves. Morrison's women's quest for freedom and for a sense of self emanate from excruciating experiences of marginalisation and abuse. Suffering for the black women is empowering rather than paralysing. Morrison asserts: "what is heroic that's the way I know why such people survive" and it's this "way" and this "why" that the next section explores at length (Guthrie,1994, p. 181).

\section{STORIES OF PAIN AND THE ETERNAL QUEST FOR FREEDOM}

Before focusing on how Morrison's female protagonists undergo trials in their search for freedom and selfrealization, it is first necessary to consider the meaning of freedom in relation to the selected novels namely The Bluest Eye, Sula, Tar Baby, Song of Solomon, and Beloved. Freedom is not a fixed concept. It has been defined and experienced by different peoples in different ways. Various thinkers have written about individual freedom, national freedom, political freedom, economic freedom, cultural freedom, and many other types of freedom classifying them into various categories and showing how each one affects the other and how they all are interrelated. From a political perspective, freedom underlines individual rights and equality of opportunity and it is understood in contrast to certain forms of human oppression.

The concept of freedom is problematic and it cannot have one single fixed meaning. It has been defined differently by different thinkers in different historical periods. Thameemul Ansari (2013) has defined freedom in political terms claiming that:

[t]he desire for freedom comes from the experience of oppression. When the experience of the oppression is common, so is the drive for freedom. The meaning of freedom remains clear as long as it is thought of as 
the redress of oppression; as the removal of this or that specific constraint, at odds with an intention most intensely felt and most painfully frustrated at the moment (p.315).

The idea of freedom has been affected by slavery. The common concerns of African American writers have been the loss of history and culture and the consequent search for roots and freedom. Their struggle for freedom has been also about gaining freedom from the image of the 'other'. The works of Morrison, which are the object of this paper, are an epitome of the war for freedom that is still, for African Americans, an ongoing phenomenon in America.

Morrison narrates her female protagonists' painful experiences and their attempt to free themselves from the various forms of oppression perpetrated by the whites and blacks alike. Her portrayal shows the impact of racism, patriarchy, and classism on the shaping of the heroines' identities and their quest for freedom. Her tales of pain bear witness to the traumas faced by black female protagonists, because of their race, gender and class in America and show their evolving consciousness leading to their freedom from the shackles of slavery, racism, sexism, and classism.

The Bluest Eye, Morrison's first novel, traces the adversities and painful experiences of a black girl named Pecola who yearns to have blue eyes, which she thinks, will end her grief and bring her the love she longs for from her hate-filled family, sarcastically named Breedlove. In this novel, the traumatic suffering of Pecola is due to the White standards of beauty. Being female and black are the causes of Pecola's suffering. Her yearning for white beauty standard of blue eyes is impossible for her to meet. Being poor is another reason for her oppressive condition. As Claudia puts it, "Being a minority in both caste and class we moved about on the helm of life" (The Bluest Eye, 1970, p.11). The words of Minha Mae "to be female in this place is to be an open wound that cannot heal. Even if scars form, the festering is ever below" (A Mercy, 2010, p.163) is what trauma is all about.

Pecola is subject to various forms of oppression from both white and black people alike. She "is the epitome of the victim in a world that reduces persons to objects and then makes them feel inferior as objects" (Davis, 1982, p. 330). There are many instances where Pecola is treated in a racist manner. For example, Yacobowski, for instance, does not want contact with Pecola because of her blackness. Pecola "has seen it lurking in the eyes of all white people. So, the distaste must be for her, her blackness" (The Bluest Eye,1970, p. 49). Yacobowski evades touching Pecola's hands when she hands over the money for the chocolate she buys. He "hesitates, not wanting to touch her hand" (The Bluest Eye, 1970, p. 49). The ultimate traumatic experience for Pecola is being raped by her own father, Cholly.

In her search for freedom, Pecola has failed to free herself from the white standards of beauty. Her failure to see the beauty in her makes her suffer from low selfesteem. Unlike Pecola, Claudia and her sister are satisfied and happy with their difference, their blackness. Claudia says: "Guileless and without vanity, we were still in love with ourselves then we felt comfortable in our skins, enjoyed the news that our senses released to us, admired our dirt, cultivated our scars, and couldn't comprehend this unworthiness" (The Bluest Eye, 1970, p.74). By enjoying their colour and feeling at ease with their skins, Claudia and her sister not only question their "unworthiness" and fight against the established White ideologies but also manage to survive and coexist within the white milieu. One should understand that beauty is not in the colour of the skin and being black is only an alternative condition of existence in the world rather than a sign of inferiority. Morrison's message, illustrated through Pecola and Claudia, is that black people should be content with their blackness and they should not give up fighting to establish themselves in an alien and hostile environment because it is the only way to find peace and happiness.

In Sula, Morrison's second novel, the main female protagonist Sula tries very hard to free herself in a hostile and oppressive world. She is victimized by sexism and racism inflicted on her by the American society. Sula's exposure to multiple traumatic events, such as the death of her mother and father, causing the death of Chicken Little, losing Nel's friendship, being black and abandoned by Ajax, has a deep psychological impact on her. Jill Matus (1998) observes that Sula is haunted by "sorrow and pain" (p.63). "Traumatic narratives are about the failed attempt to free oneself, the impossibility of escape" (Ben Beya, 2010, p. 98). Morrison clarifies, "freeing yourself was one thing; claiming ownership of that freed self was another" (Beloved, 1987, p. 95), which means that the entanglement remains intact even after freeing oneself. The latter creates the "ethical responsibility" to tell. To witness is to hear history from the perspective of the traumatized subject" (Ben Beya, 2010, p. 98). Morrison gives Sula a space and voice to tell her painful story. The novel depicts the heroine's journey of quest for freedom and a meaningful identity in a world of growing hostility.

Sula's extreme emotional impulses and her strange, strong, and independent character startle the community in which she lives. These are shown in her rejection of all behavioural standards and values of society and her attempts to create her own standards. She rejects the marriage's and motherhood's limits and obligations by 
leaving the Bottom and going away seeking emotional and physical freedom from society's order and control. Anne Mickelson (1979) portrayed her as the rebel, "who exceeds boundaries, creates excitement, tries to break free of encroachment of external cultural forces, and challenges destiny" (p. 129). To Eva's question "when you gone to get married? You need to have some babies. It'll settle you", Sula replies, "I don't want to make somebody else. I want to make myself" (Sula, 2004, p.92). Unlike Eva who sacrifices her physical freedom for economic freedom and Nel who accommodates herself to the protection of marriage, Sula resists both sacrifice and accommodation.

Sula's freedom from the signifieds of racial degeneracy, from fear and her tough and rebellious character are reasons behind her self-empowerment. Sula "was completely free of ambition, with no affection for money, property or things, no greed, no desire to command attention or compliments- no ego. For that reason, she felt no compulsion to verify herself- be consistent with herself ... And like any artist with no art form..." (Sula, 2004, pp. 119-121). Here again, Morrison portrays Sula as a revolutionary character to be followed by oppressed women who must revolt against their oppressors who block their ways to freedom.

Morrison's female protagonists try to gain their freedom and assert their black identity by protesting against the white and black oppressive forces. Though all the main female protagonists are oppressed by the principal male characters only a few women characters like Pilate Dead, Corinthians and Lena in Song of Solomon and Jadine and Ondine in Tar Baby protest against their oppressors. Pilate's loss of her mother since her birth and being deprived of the loving father since twelve have filled her life with grief. The disenchanted memories of her early childhood agonize and alienate Pilate. However, she is able to survive in the black American society by creating a world of her own. She manages to face these adversities and to carve out a space of her own. Similarly, Corinthians attempts to assert her black identity by having a job and leaving the hostile environment in which she lives.

In Tar Baby, Jadine Childs's trauma is due to her double consciousness, her desire to be loyal to both American and African American cultures. She forgets her ancestry; she is mad about New York and the white culture. She has a strong will and she wants her economic freedom. Being free and independent is what matters most for Jadine. She is ready to drop anybody who blocks her way to freedom even the person she loves very much. Similarly, Ondine, who is a servant, values her freedom and independence. She dares to give her mistress a smack in her husband's presence when she abused her. Jadine and
Ondine are rebels who raise their voice of protest both against white and black oppressors.

Although she works as a model in Europe, Jadine knows that she is neither accepted in the White society nor in the Black society. She is rejected by both the white and black communities. For Jadine, economic success is her way to equality with the White. Unlike Jadine, Son thinks that one must understand one's history first and one should not forget one's own culture. Jadine values her freedom and independence. She rebels against her blackness and she yearns for an independent free self. Patrick Bjork (1992) argues that Jadine's “acceptance of disconnection from a cultural heritage serve as an indictment against her for denying the cultural knowledge that may further empower her" (p.138). Jadine represents the new African American youth who are indoctrinated by the formal education and the dominant White values.

Jadine is able to manage the oppressive class system but she fails to value her own culture and tradition. She represents Morrison's emancipated new woman, who breaks the age-old traditions and conventions set up by patriarchy, race, gender, and class bias. She succeeds to live a life free of race, gender, and class but she fails to resolve her inner conflict about her racial identity. This may be taken as Morrison's suggestion that for a black female to attain a wholesome personality she should have clear understanding of her history, culture, and identity.

"Those white things have taken all I had or dreamed and broke my heartstrings too. There is no bad luck in the world but white folks" (Beloved, 1987, p. 89) Baby Suggs, a character in Morrison's Beloved says to her daughter Sethe. Suggs's words encapsulate the African Americans' dilemma, the centuries of oppression, racism, and traumatic experiences they have been through since the Middle Passage at the hands of white people. In the twenty-first century and in the purported "post-racial" America, there are continuing racial injustice and widespread murdering and other forms of violence against the Afro-Americans. Slavery has officially ended after all the abolitionist, Civil Rights and Liberation Movements but the black people are still physically and psychologically oppressed in America.

As a trauma narrative, Morrison's fifth novel Beloved "is framed around the necessity to tell, the forceful commandment to bear witness and to testify, confessing the truth of horror" (Ben Beya, 2010, p. 96). Beloved narrates the historical trauma of slavery, which is the most agonizing period in the Black people's history. The novel is a haunting blend of the past and present traumatic experiences of Sethe, a female freedom seeker. As Morrison says, "this was not a book about the institution - 
Slavery with a capital S. It was about these anonymous people called slaves. What they do to keep on, how they make a life, what they're willing to risk, however long it lasts, in order to relate to one another" (Angelo, 1994, p. 257). Sethe kills her infant to free her from the shackles of slavery, a haunting event which causes her sense of guilt and grief. For Ranveer (1995), Sethe "is fated, but she tries to liberate herself and her children from this given fate" ( $p$. 43). Morrison dares to speak out the unspeakable and rips the veil on the hidden realities of sore ordeals. She examines the deep physical and psychological wounds of slavery and recalls Sethe's bold flight to freedom in Ohio in 1855. Freedom, as Paul D's and Sethe's painful stories illustrate, "is to get to a place where you could love anything you chose--not to need permission for desire" (Beloved, 1987, p. 162).

Sethe is in constant search for freedom. She is deprived of her mother's milk as a child and of a proper marriage when she is young. Her breast milk is taken from her by force and it is given to her slave master. She has been struggling for survival and protesting against the horrors of slavery. Sethe's plan to escape from her White master's house and her decision to marry Halle are her first steps towards gaining her freedom and establishing her identity. Her tough decision to kill her own children in order to free them from the shackles of slavery signify her strong desire for life free of bondage. Similarly, Denver, Sethe's second daughter, becomes highly independent and strong, supporting her mother by the end. Her bravery and responsibility help her protest against her past oppressed life and save her family from ruin. She has become a free being interacting freely with members of her community. Being the only remaining child of Sethe, Denver represents the future. The recollection and recreation of Sethe's repressed memories "are essential to her recovery" (Krumholz, 1992, p. 395). Memory is essential for her to achieve her freedom.

\section{DISARTICULATING POST-RACIAL DISCOURSE}

Morrison and the BLM activists share a common goal which is the eradication of the roots of racism and the attainment of freedom for the black race. Therefore, her narratives and those of the BLM movement complete each other and they demonstrate the inextricable relationship between the literary text (Morrison's novels) and the social context (BLM) in their attempt to denounce the unjust structures and oppressive systems of the American society and to disarticulate the post-racial discourse of the dominant white authorities. Although they use different means and narratives, the Black Lives Matter movement and Morrison have exposed the contradictions in American society and have brought to light the reality of oppression that the African Americans experience behind the seemingly empowering rhetoric of the dominant class. They have revealed the deplorable status of African Americans and how they were treated as slaves before Emancipation and how they have become objects of active antagonism after their liberation.

There is no denying the fact that Morrison's writings and the Black Lives Matter protests and activism have made a powerful impact on the psyche of the colonial masters. But the questions which remain to be answered today convincingly are whether the conditions of African Americans in America have improved any better since then. Is the African American context postcolonial? How do African Americans engage with an oppressive system where freedom and justice are promised but never given? Morrison's novels and the BLM narrative are not simply narratives of oppression; but they are spaces to imagine a new society which supports racial equality and black dignity. Their main goal is not to simply eradicate the old unjust structures of the American society but to create new structures in which black lives matter. Robin D. G. Kelley (2002) states that "struggle is par for the course when our dreams go into action. But unless we have the space to imagine and a vision of what it means fully to recognize our humanity, all the protests and demonstrations in the world won't bring about our liberation" (p.198).

It is significant that the BLM movement is founded and headed by black women namely Alicia Garza, Patrisse Cullors, and Opal Tometi. This movement has become a voice for black female leadership and for all African Americans. As I have already stated, Morrison's novels and the BLM narrative have attempted to imagine and to dream a society where freedom and justice are a reality for black Americans, because as Kelley (2002) argues "without new visions [they] don't know what to build, only what to knock down" (p.xii). Both literary expression and social activism can provide ways to critique the unjust structures of racism and the oppressive systems of the American society and to imagine and develop alternative visions.

Through her writings and through their protests and demonstrations, Morrison and the BLM activists respectively have attempted to shake the white people's collective memories out of dis-remembrance of black lives, to ensure that the lives that have been lost are not erased from history and to demand accountability from abusers and full visibility and equality for African Americans. It is through these same demands African American writers and activists should continue the historic struggle for civil rights. They should continue to fight for 
freedom until Black Lives Matter. The foundation for ensuring black lives matter is freedom. These protests in words and in action are more than mere renunciations of violence, racism, and all forms of oppression-they are quests for freedom.

Both Morrison's novels and the BLM present and denounce the abhorrent reality of racism and racial discrimination in the American society. Race, as a social rather than a biological construction, is at the centre of their narratives. The significance of Morrison's novels emanates not only from the examination of the nature of race and its traumatic effects on her black characters but also from their relevance in the context of the Black Lives Matter movement and the recent George Floyd protests. The fact that the American society is still shaped by the concept of race reveals the big lie of "post-racial" America and therefore, the examination of race and racial prejudice is of paramount importance nowadays. Race and racial prejudice have been shaping the history, politics, the society, and the culture of America. Thinking about the recent uprisings of the Black Lives Matter against police violence prompted by the murder of George Floyd, one is tempted to question the Politicians' assertion that there is a remarkable change in the African-Americans' lives and that today they are no longer victimized socially, economically, and politically. How should one react to such assertions? Shall we accept them as a fact? Shall we deny those purported radical changes? Shall we keep silent or be cynical? The recent Black Lives Matter protests confirm that African Americans are still victims of social exclusion and racism in America. These recent global Black Lives Matter uprisings against police violence prompted by George Floyd's murder cannot be viewed solely as something in the past, but rather as an ongoing wound of enslavement and a very pressing issue affecting the American society even nowadays, in the twenty-first century. According to Andrew Curran (2020), "[t]he histories of slavery and racism in the United States have never been more pertinent" (n.p.n).

Although Morrison's selected novels and the BLM are two different modes of narrative, they are about the ongoing wounds of enslavement, they both lay bare the mental and physical wounds of African Americans and they assert the continuity of African Americans' traumas and systematic racism in America. The African Americans have remained the object of racism, oppression, and violence after the Civil War and the Reconstruction Era and are even so today. There are common goals between Morrison's selected novels and the Black Lives Matter movement. First, they share the same aim of giving voice to the voiceless and marginalized black people and providing representation and visibility for Black lives.
Morrison used her fiction to ensure that black lives matter and their voices heard.

Morrison's novels and the BLM movement investigate aspects of the oppression afflicting black people and they reject racially motivated violence against them be it police violence or any other forms of violence. The BLM and Morrison's novels are mainly prompted by the racism that normalizes violence against Black men, women, and children. They denounce and refuse the deadly equation of Americanness with whiteness. Morrison's novels and the BLM attest to the fact that race and racism remain pervasive elements of twenty-first-century American society. Both narratives highlight the unfinished business of the civil rights movement of the 1950s and 1960s; not only the systemic racism of the failure to hold police officers accountable for extrajudicial killings, but also poverty and economic inequality. To juxtapose Morrison's novels with the political work of Black Lives Matter movement is meant to show how the two narratives complete each other and to demonstrate the inextricable relationship between the literary text and the social context.

\section{CONCLUSION}

To conclude, this paper examines the quest for freedom in Morrison's selected novels and draws parallels between her writings and the BLM's narrative. Although they are two different narratives, they share common goals of destabilizing racial hierarchies, laying bare the atrocities inflicted on the black people, and fighting, in words and in actions, all forms of oppression against black people in order to attain the freedom they have been denied since slavery. They call for a social change regarding the inherent issues of trauma, racism, and injustice that the African Americans have suffered from throughout history. From a postcolonial perspective, Morrison's novels constitute a counter discourse to dominant ideologies and representations because she wrote them in order to dismantle, demystify and unmask the dominant white community and its oppressive systems and to define a denied or outlawed self.

Morrison portrays different phases in the lives of AfroAmericans showing their journeys toward freedom. Pecola, in The Bluest Eye, Sula in Sula, Pilate in Song of Solomon, Jadine in Tar Baby and Sethe and Denver in Beloved are Morison's heroines who illustrate the atrocities perpetrated on the blacks by the white American institutions and their attempt to free themselves from the various forms of oppression inflicted on them. African American women have been victims of slavery, sexism, racism, and classism. These are the problems that the 
Black females confront even today. In Morrison's selected novels, there are implicit messages to the black community as a whole. Her first message is that the black people must blend their past memories and experiences into their present lives so that they can truly demand their freedom. Although freedom is a personal dream in the first place, it converts to nothing if isolated from the more comprehensive collective communal vision. The black people need to purify themselves from Whiteness: For a black woman/man to acquire an identity, s/he must first purify himself/herself from 'whiteness'. To use DuBois's words "to attain his place in the world, he must be himself, and not another" (p.20). S/he should be convinced that a new other self is to be created. Yet, s/he should realize that it is only herself/himself who could do it.

Men and women should act as members of one race. The wholeness between men and women is essential to reach their dream of freedom. Loving one's flesh is another way to freedom. This is clear, for instance, in Baby Suggs's advice to ex-slaves to "Love your hands! Love them. Raise them up and kiss them. Touch others with them, pat them together, stroke them on your face' cause they don't love that either. [...] hear me now, love your heart. For this is the prize" (Beloved, 1987, p.89). The black flesh that the whites despise should be a sign of pride rather than one of shame.

Morrison advocates love and solidarity as another way to attain freedom. All Black women should come together as one class to gain their freedom and discover their own identities through their bonding with one another. Here Morrison echoes James Baldwin (2013) when he explains the meaning of the word "integration" which denotes that "we, with love, shall force our brothers to see themselves as they are, to cease fleeing from reality and begin to change it" (p.23). Finally, assuming responsibility, which for Morrison, is very important in moulding an identity and being free. For her, freedom and responsibility are inextricably intertwined. She tells Gloria Naylor: "The point is that freedom is choosing your responsibility. It's not having no responsibilities; it's choosing the ones you want" (Naylor, 2004, p.16). Responsibility is a precondition that freedom necessitates; it prepares people for their new selves. It is only when people 're-connect' themselves to their community that is ruled by love, a clear understanding of one's history, solidarity, and responsibility, either personal or communal, that they could reach their freedom.

Morrison is preoccupied with the racial, gender and class issues, common to many of her novels, which she sees as impediments to freedom and social justice in America. This marks an invitation to further explore what it means to be a Black man/woman in the United States today and to examine how Morrison disarticulates postracial, post-black, and post-feminist discourses in her latest novels namely Love (2003), A Mercy (2008), Home (2012), and God Help the Child (2015). This is a significant and pertinent issue which can be the object of a future research.

\section{REFERENCES}

[1] Andrew, C. (2020, July 10). Facing America's history of racism requires facing the origins of 'race' as a concept. TIME. https://time.com/5865530/history-race-concept/.

[2] Angelo, B. (1994). The pain of being black: An interview with Toni Morrison. In Daniel. T.G (Ed.), Conversations with Toni Morrison (pp. 255-261). Jackson: University of Mississippi Press.

[3] Baldwin, J. (2013). The fire next time. Vintage.

[4] Ben Beya, A. (2010). The question of reading traumatic testimony: Jones's Corregidora and Morrison's Beloved. Alif: Journal of Comparative Poetics, (30), 85-109.

[5] Bjork, Patrick Bryce. 1992. The novels of Toni Morrison: The search for self and place within community. New York: Peter Lang.

[6] Britannica, T. Editors of Encyclopaedia (2021, September 14). Black Lives Matter. Encyclopedia Britannica. https://www.britannica.com/topic/Black-Lives-Matter.

[7] Buckman, A. R. (1995). The body as a site of colonization: Alice Walker's possessing the Secret of Joy. The Journal of American culture, 18(2), 89.

[8] Chapagain, R. P. (2020). African American women, racism and triple oppression. Interdisciplinary Journal of Management and Social Sciences, 1(1), 113-117. https://doi.org/10.3126/ijmss.v1i1.34615.

[9] Dastageer, A. (2016). The struggle for survival to the joy of liberation a study of the evolution of black female consciousness in the novels of Toni Morrison $[\mathrm{PhD}$ thesis, Bharathidasan University]. Bharathidasan University Research Repository. http://hdl.handle.net/10603/117427.

[10] Davis, C. A. (1982). Self, society, and myth in Toni Morrison's fiction. Contemporary Literature, 23(3), 323342. https://doi.org/10.2307/1208158. Accessed 24 May 2021.

[11] D'Haen, T. (1993). Shades of empire in colonial and postColonial literatures (Introduction). In C. C. Barfoot and Theo D'Haen (Eds.), Shades of empire in colonial and postcolonial literatures (pp. 9-16). Amsterdam: Rodopi.

[12] Du Bois, W. E. (2015). I. Of our spiritual strivings (pp. 311). Yale University Press

[13] Taylor-Guthrie, D. (Ed.). (1994). Conversations with Toni Morrison. University Press of Mississippi.

[14] Hooks, B. 1981. Ain't I a Woman: Black women and feminism. Boston: South End Press.

[15] Hooks, B. (1994). Outlaw culture. New York: Routledge.

[16] Hooks, B. (1990). Yearning: Race, gender, and cultural politics. Boston: South End Press.

[17] Hooks, B. (1992). Black looks: Race and representation. Boston: South End P. 
[18] Konomi, A. (2020, August 11). Vox populi: Reading Toni Morrison offers insight into Black Lives Matter. asahi.com, The Asahi Shimbun, 2020/08/11/ http://www.asahi.com/ajw/articles/13625842. Accessed 28 May 2021.

[19] Krumholz, L. (1992). The ghosts of slavery: Historical recovery in Toni Morrison's Beloved. African American Review, 26(3), 395-408.

[20] Lister, R. (2009). Reading Toni Morrison. Santa Barbara, CA: Greenwood.

[21] Mairhofer, E. and Meister M. (2007). (Postcolonial Theory) from margin to center and half-way back. In Hölbling, W. (Ed.). Theories and texts: For students, by students (Vol. 7). LIT Verlag Münster.

[22] Matus, J. (1998). Toni Morrison. Manchester and New York: Manchester University Press.

[23] Mickelson, A. Z. (1979). Reaching out: Sensitivity and order in recent American fiction by women. Metuchen, NJ: Scarecrow Press.

[24] Morrison, T. (1970). The Bluest Eye. London: Pan.

[25] Morrison, T. Sula. (2004). New York: Vintage International.

[26] Morrison, T. (1977). Song of Solomon, London: Pan.

[27] Morrison, T. (1981). Tar Baby. London: Pan.

[28] Morrison, T. (1987). Beloved. New York: Signet.

[29] Morrison, T. (2010). A Mercy. London: Vintage Books.

[30] Naylor, G. (2004). Conversations with Gloria Naylor. Univ. Press of Mississippi.

[31] Ranveer, K. (1995). Black feminist consciousness: A study of black women writers, Printwell, Jaipur.

[32] Robinson, D. E. (2001). Black nationalism in American politics and thought. Cambridge: Cambridge University Press.

[33] Robin D. G. K. (2002). Freedom dreams: The black radical imagination. Boston: Beacon Press.

[34] Tiffin, Helen (1988). Post-Colonialism, post-Modernism and the rehabilitation of post-colonial history. Journal of Commonwealth Literature 23(1), 169-81.

[35] Wu, H. (2010). Post-Mao Chinese literary women's rhetoric revisited: A case for an enlightened feminist rhetorical theory. College English, 72(4), 406-423. 